\title{
Hubungan Antara Sikap Religiusitas Dengan Perilaku Hidup Bersih dan Sehat (PHBS) Di Rumah Tahfidz X
}

\author{
Defpri Hs $^{1^{\star}}$, Dewi Pujiana ${ }^{2^{\star \star}}$, Aristoteles ${ }^{3^{\star \star \star}}$ \\ ${ }^{1}$ Mahasiswa Program Studi IImu Keperawatan IKesT Muhammadiyah Palembang \\ 2Dosen Program Studi IImu Keperawatan IKesT Muhammadiyah Palembang \\ 3Dosen Teknologi Laboratorium Medis IKesT Muhammadiyah Palembang \\ Korespondensi Email: defprih@gmail.com
}

\begin{abstract}
ABSTRAK
Pendahuluan: Sikap religiusitas adalah suatu pikiran, kecenderungan, dan perasaan seseorang untuk mengenali aspek-aspek pengetahuan agama, pelaksanaan ibadah dan kaidah dan seberapa dalam penghayatan atas agama yang dianutnya dan keyakinan yang telah diperoleh semasa hidup, yang nantinya dapat menjadi penentu dan landasan dalam berperilaku saat mengambil suatu tindakan dan diataranya adalah dalam perilaku hidup bersih dan sehat (PHBS). Metode:Jenis penelitian yang digunakan dalam penelitian ini adalah deskriptif korelasi yang menggunakan desain penelitian kuantitatif, dengan pendekatan cross sectional. Teknik sampling, total sampling dengan total 39 responden. Pengambilan data menggunakan kuesioner Sikap Religiusitas dan PHBS. Hasil: analisis hubungan antara sikap religiusitas dengan PHBS sebanyak $13(33,3 \%)$ responden, sedangkan responden dengan sikap religiusitas tinggi tetapi memiliki PHBS yang kurang baik sebanyak 7 (17,9\%) responden. Responden dengan sikap religiusitas rendah dengan PHBS yang baik ada sebanyak 5 (12,8\%), dan responden dengan sikap religiusitas rendah dan memiliki PHBS yang kurang baik ada sebanyak $14(35,9 \%)$. Dari hasil uji statistik Chi Square diperoleh nilai $p$ value $=0,036(p<\alpha 0,05)$ yang berarti ada hubungan antara sikap religiusitas dengan PHBS. Kesimpulan: terdapat hubungan antara sikap religiusitas dengan perilaku hidup bersih dan sehat di rumah tahfidz (Rumah Qur'an Mulia) Palembang.
\end{abstract}

\section{Kata kunci:Sikap Religiusitas, PHBS, Rumah Tahfidz}

\section{The Relationship Between Religious Attitude with Clean and Healthy Living Behavior (PHBS)} at Tahfidz House $X$

\begin{abstract}
Introduction: Attitude of Religiosity is a thought, tendency, and feeling of a person to recognize aspects of Religious knowledge, the implementation of worship and rules and how deep the appreciation of the religion they embrace and the beliefs that have been acquired during life, which later can become determinants and foundation in behave when taking an action and for example is in a clean and healthy lifestyle (PHBS). Method:The type of research used in this study was descriptive correlation that used quantitative research design, with a cross sectional approach, total sampling with a was 39 respondents. The data was taken by using questionnaires Attitudes of Religiosity and PHBS. Result: The analysis of the correlation between attitude of religiosity and clean and healthy behavior was obtained by respondents with a high attitude of religiosity with good PHBS There were 13 (33.3\%) respondents, while respondents with high religious but had poor PHBS were 7 (17.9\%) respondents. Respondents with a low religiosity with good PHBS were 5 (12.8\%), and respondents with a low attitude of religiosity and poor PHBS were 14 (35.9\%). From the results of the Chi Square statistical test, the value of pvalue $=0.036(p<\alpha 0.05)$ which means that there was a correlation between the attitude of religiosity and PHBS. Conclusion: there is a relationship between the attitude of religiosity with clean and healthy living behaviour in the tahfidz house (Rumah Qur'an Mulia) Palembang.
\end{abstract}

Keywords: Religious Attitude, PHBS, Tahfidz House 


\section{PENDAHULUAN}

Rumah tahfidz merupakan gabungan dari kata rumah dan tahfidz. Rumah berarti bangunan untuk tempat tinggal, sedangkan tahfidz berasal dari kata hafadzo yang artinya menjaga. Adapun yang dimaksud disini adalah menjaga dengan menghafal Al-qur'an (Mahardhika, 2003). Dari pengertian tersebut dapat disimpulkan bahwa rumah tahfidz Alqur'an merupakan rumah yang dipergunakan sebagai tempat menghafal Al-qur'an.

Rumah tahfidz yang sama juga halnya dengan pondok pesantren yang juga memiliki permasalahan yang sama dalam bidang kesehatan, seperti masalah perilaku hidup bersih dan sehat (PHBS). Adapun permasalah PHBS yang seringkali muncul dalam pondok pesantren diantaranya kepadatan hunian kamar, sarana pembuangan sampah, sarana jamban sehat yang kurang memadai dan penyediaan air bersih santri, sering menggantung pakaian di kamar, saling bertukar benda pribadi seperti pakaian, sisir dan handuk (Nugraheni \& Nurlina, 2008).

Penelitian yang dilakukan oleh Zuhriya (2015) di pondok pesantren Mamba'us Syafa'atil Qur'an menunjukkan perilaku hidup bersih dan sehat santri sebesar $31,25 \%$ dalam kategori baik, 42,5\% cukup, dan 26,25\% kurang. Perilaku hidup bersih dan sehat (PHBS) santri yang sudah baik yaitu, selalu mencuci tangan sebelum makan dan setelah buang air besar serta tidak ada santri yang pernah menggunakan narkoba, sementara
PHBS santri yang kurang yakni tindakan menghindari penularan penyakit.

Penelitian lain oleh Parman dkk., (2017) di pesantren Al-baqiyatushshalihat didapatkan hasil yang menunjukkan bahwa sebanyak 50\% responden menderita scabies (kasus), 42,1\% responden memiliki kebersihan kulit kurang baik, 50\% responden memiliki kebersihan tangan dan kuku kurang baik, 31,0\% responden memiliki kebersihan genital kurang baik, 45,2\% responden memiliki kebersihan pakaian kurang baik, 47,6\% responden memiliki kebersihan handuk kurang baik, $57,9 \%$ responden memiliki kebersihan tempat tidur dan sprei kurang baik.

Dari penelitian yang dilakukan oleh peneliti sebelumnya di beberapa pondok pesantren di Indonesia dapat disimpulkan bahwa program perilaku hidup bersih dan sehat (PHBS) di pondok pesantren masih berada dalam kategori cukup yang dapat dilihat dari hasil penetilian yang menunjukan bahwa kategori cukup menjadi predikat tertinggi dari setiap hasil penelitian. Dari belum terlaksana sepenuhnya program PHBS di pondok pesantren/ rumah tahfidz di Indonesia, penentuan sikap menjadi hal yang penting dalam mengatur perilaku dalam bidang kesehatan terutama perilaku hidup bersih dan sehat (PHBS) yang ada di pondok pesantren dan rumah tahfidz.

Sikap adalah keyakinan atau pendapat seseorang terkait situasi, subjek atau objek yang disertai dengan munculnya perasaan tertentu. Perasaan inilah yang akan dijadikan 
sebagai dasar orang tersebut untuk berperilaku dan merespon menggunakan cara tertentu sesuai dengan pilihannya (Walgito, 2001).

Religiusitas seringkali diidentikkan dengan keberagamaan. Religiusitas diartikan sebagai seberapa jauh pengetahuan, seberapa kokoh keyakinan, seberapa pelaksanaan ibadah dan kaidah dan seberapa dalam penghayatan atas agama yang dianutnya. Bagi seorang Muslim, religiusitas dapat diketahui dari seberapa jauh pengetahuan, keyakinan, pelaksanaan dan penghayatan atas agama Islam (Nashori, Fuad, \& Mucharam, 2002)

Dari pengertian sikap dan religiusitas diatas dapat disimpulkan bahwa sikap religiusitas adalah suatu pikiran, kecenderungan, dan perasaan seseorang untuk mengenali aspek-aspek pengetahuan agama, dan keyakinan yang telah diperoleh semasa hidup, yang nantinya dapat menjadi penentu dan landasan dalam berperilaku saat mengambil suatu tindakan dan diataranya adalah dalam perilaku hidup bersih dan sehat (PHBS).

PHBS perlu diterapkan dalam berbagai tatanan tempat dimana sekumpulan suatu individu hidup, berinteraksi, bekerja, dan bermain. Menurut Kemenkes RI (2011),PHBS mencakup semua perilaku yang harus dipraktikkan di bidan pencegahan dan penanggulangan penyakit, penyehatan lingkungan, kesehatan ibu dan anak, keluarga berencana, gizi, farmasi dan pemeliharaan kesehatan. Perilaku-perilaku tersebut harus dipraktikkan dimanapun seseorang berada yang diantaranya telah dibagi menjadi 5 tatananPHBS yaitu Rumah Tangga, Institusi Pendidikan, Tempat Kerja, Sarana Kesehatan, dan Tempat-Tempat Umum.

Penerapan PHBS tersebut dilaksanakan terhadap 5 tatanan, diantaranya adalah tatanan rumah tangga. Terdapat 10 indikator PHBS tatanan rumah tangga, yaitu pertolongan persalinan oleh tenaga kesehatan, bayi diberi ASI ekslusif, mempunyai jaminan pemeliharaan kesehatan, ketersediaan air bersih, ketersediaan jamban sehat, kesesuaian luas lantai dengan jumlah penghuni, lantai rumah bukan lantai tanah, tidak merokok di dalam rumah, melakukan aktifitas fisik setiap hari, dan makan buah dan sayur setiap hari. Keberhasilan program PHBS tatanan rumah tangga didasarkan kepada 10 indikator yang dibagi menjadi 4 kategori, yaitu: Sehat I, Sehat II, Sehat III, dan Sehat IV, dengan target pemerintah yaitu tercapainya penduduk Indonesia yang berPHBS pada tingkat Sehat IV (Kermenkes RI, 2010).

\section{BAHAN DAN METODE}

Desain Penelitian, jenis penelitian yang digunakan dalam penelitian ini adalah deskriptif korelasi. Tujuan dari penelitian ini adalah untuk mengetahui hubungan antara dua variabel bebas (sikap religiusitas) dan variabel terikat (perilaku hidup bersih dan sehat).Penelitian ini menggunakan desain penelitian kuantitatif, dengan pendekatan cross sectional. 
Populasi, didalam penelitian ini berjumlah berjumlah 46 orang santri dengan total santri putra sebanyak 39 orang dan santri putri sebanyak 7 orang. Sampel penelitian,Teknik sampling yang digunakan dalam penelitian ini adalah Total Sampling. Adapun sampel yang di ambil dalam penelitian ini adalah suluruh santri putra di (Rumah Qur'an Mulia Palembang) tahun 2019 berjumlah 39 orang santri.

Cara pengumpulan data yaitu dengan menggunakan kuesioner. Kuesioneryang digunakan dalam penelitian ini adalahkuesioner sikap religiusitas dan kueioner perilaku hidup bersih dan sehat (PHBS).

Kuesioner sikap religiusitas, digunakan untuk mengetahui sikap religiusitas responden. Pada kuesioner ini yang digunakan adalah kuesioner yang dibuat oleh peneliti sebelumnya dengan jumlah pertanyaan sebanyak 30 item pertanyaan dengan jenis pertanyaan Favorable dan Unfavorable. Jenis pertanyaan Favorable pilihan pertanyaan jawaban bila sangat setuju skornya 4 , bila setuju skornya 3 , bila tidak setuju skornya 2 , bila sangat tidak setuju skornya 1. Sedangkan jenis pertanyaan Unfavorable pilihan jawaban bila sangat setuju skornya 1 , bila setuju skornya 2 , bila tidak setuju skornya 3 , bila sangan tidak setuju skornya 4. Nilai pengukuran sikap religiusitas dikelompokan menjadi 2 kategori yaitu tinggi, jika skor religiusitas $\geq$ mean, dan rendah, jika skor religiusitas $<$ mean.
Kuesioner PHBS, yang digunakan untuk mengetahui perilaku hidup bersih dan sehat (PHBS) santri di rumah tahfidz (Rumah Qur'an Mulia Palembang). Pada kuesioner ini yang digunakan adalah kuesioner yang dibuat oleh peneliti sebelumnya dengan jumlah pertanyaan sebanyak 45 item pertanyaan dengan jenis pertanyaan Favorable dan Unfavorable. Jenis pertanyaan Favorable pilihan pertanyaan jawaban bila Selalu dilakukan skornya 4, bila Sering dilakukan skornya 3, Kadang-kadang dilakukan skornya 2, bila Tidak pernah dilakukan skornya 1 . Sedangkan jenis pertanyaan Unfavorable pilihan jawaban bila Selalu dilakukan skornya 1, bila Sering dilakukan skornya 2, Kadangkadang dilakukan skornya 3 , bila Tidak pernah dilakukan skornya 4. Adapun nilai untuk hasil dikelompokan menjadi 2 kategori yaitu baik, jika skor $\mathrm{PHBS} \geq$ mean,dan rendah, jika skor PHBS $<$ mean.

Uji validitas pada kuesioner sikap religusistas yang diadopsi dari kuesioner Rifqi (2011) dengan 35 pertanyaan dan telah dilakukan uji validitas. Terdapat 5 item pertanyaan yang gugur dalam uji validitas dengan hasil pengujian yang dinyatakan valid jika nilai reabilitasnya 0,8143 , sehingga yang digunakan dalam penelitian hanya 30 pertanyaan.

Kuesioner perilaku hidup bersih dan sehat (PHBS), yang diadopsi dari kuesioner Nasyith (2018) dengan 60 pertanyaan. Menurut Nasyith pada penelitian nya: Nilai $r$ xy yang diperoleh akan dikonsultasikan dengan harga product moment pada pada taraf signifikansi 
0,05 . Bila nilai korelasi $r$ hitung $\geq 0,304$, maka pertanyaan dalam kuesioner dinyatakan valid. Sebaliknya apabila nilai korelasi $r$ hitung $<0,304$ maka pertanyaan dalam kuesioner yang digunakan dalam penelitian hanya 45 pertanyaan.

Analisa data dilakukan dengan analisa data univariat dan bivariat untuk mengetahui persentase dan variabel prilaku hidup bersih dan sehat (PHBS) di rumah tahfidz (Rumah Qur'an Mulia Palembang).

Analisa univariat dalam penelitian ini analisa univariat menjelaskan atau mendeskripsikan karakteristik setiap variabel penelitian dari data-data karakteristik responden penelitian. Analisis bivariat, pada penelitian ini analisis bivariat dilakukan untuk mengetahui hubungan antara sikap religiusitas (variabel independen) dengan prilaku hidup bersih dan sehat (PHBS) (varibel dependen) di (Rumah Qur'an Mulia Palembang) melalui uji chi square. Uji statistik yang digunakan adalah chi square, uji chi square digunakan untuk menguji hipotesis bila dalam populasi terdiri atas dua atau lebih kelas dimana datanya berbentuk kategorik.

HASIL

Analisis Univariat

Karakteristik Responden Berdasarkan Usia

Tabel 1.

Distribusi Frekuensi (Usia Responden)

\begin{tabular}{ccccc}
\hline $\begin{array}{c}\text { Jumlah } \\
\text { Responden }\end{array}$ & SD & $\begin{array}{c}\text { Mean- } \\
\text { Median }\end{array}$ & $\begin{array}{c}\text { Min- } \\
\text { Max }\end{array}$ & 95\%Cl \\
\hline 39 & 2,307 & $20,31-$ & $15-$ & $19,59-$ \\
& & 20,00 & 26 & 21,06 \\
\hline
\end{tabular}

tidak valid. Setelah dilakukan uji validitas hasil pengujian menunjukan terdapat 15 item pertanyaan yang gugur dan tidak digunakan dalam penelitian. Sehingga total pertanyaan

Dari tabel distribusi statistik di atas, jumlah rata-rata usia responden yaitu 20,31 tahun, dan nilai tengah usia responden yaitu 20,00 tahun, dengan standar deviasi usia 2,307 tahun. Responden dengan usia terendah yaitu 15 tahun berjumlah 2 responden, dan usia tertinggi 26 tahun berjumlah 1 responden, dari hasil estimasi interval dapat disimpulkan bahwa $\mathrm{Cl}$ diyakini rata-rata usia responden berkisar antara 20 sampai 22 tahun.

\section{Responden Sikap Religiusitas}

Tabel 2.

Distribusi frekuensi (sikap religiusitas)

\begin{tabular}{clcc}
\hline No & $\begin{array}{c}\text { Sikap } \\
\text { Religiusitas }\end{array}$ & Total & Persentase \\
\hline 1. & Tinggi & 20 & $51,3 \%$ \\
\hline 2. & Rendah & 19 & $48,7 \%$ \\
\hline & Jumlah & 39 & $100 \%$ \\
\hline
\end{tabular}

Dari tabel distribusi frekuensi di atas, responden yang memiliki sikap religiusitas tinggi berjumlah 20 responden $(51,3 \%)$ dan responden yang sikap religiusitasnya rendah berjumlah 19 responden $(48,7 \%)$.

\section{Responden dengan Perilaku Hidup Bersih dan Sehat}

Tabel 3.

Distribusi frekuensi perilaku hidup bersih dan sehat (PHBS)

\begin{tabular}{clcc}
\hline No & $\begin{array}{l}\text { Perilaku hidup } \\
\text { bersih dan sehat }\end{array}$ & Total & Persentase \\
\hline 1. & Baik & 18 & $46,2 \%$ \\
\hline 2. & Kurang Baik & 21 & $53,8 \%$ \\
\hline & Jumlah & 39 & $100 \%$ \\
\hline
\end{tabular}


Sumber: Data Primer

Dari tabel distribusi frekuensi di atas, responden dengan Perilaku Hidup Bersih dan Sehat yang baik berjumlah 18 responden
(46,2\%), responden dengan Perilaku Hidup Bersih dan Sehat yang kurang baik berjumlah 21 responden $(53,8 \%)$.

\section{Analisis Bivariat}

Tabel 4.

Distribusi frekuensi hubungan antara sikap religiusitas dengan perilaku hidup bersih dan sehat

\begin{tabular}{|c|c|c|c|c|c|c|c|c|}
\hline \multirow{3}{*}{$\begin{array}{l}\text { Perilaku Hidup Bersih } \\
\text { dan Sehat (PHBS) }\end{array}$} & \multicolumn{6}{|c|}{ Sikap Religiusitas } & \multirow{3}{*}{$\begin{array}{l}\text { OR } \\
95 \%\end{array}$} & \multirow{3}{*}{ P-Value } \\
\hline & \multicolumn{2}{|c|}{ Tinggi } & \multicolumn{2}{|c|}{ Rendah } & \multicolumn{2}{|c|}{ Total } & & \\
\hline & $\mathrm{N}$ & $\%$ & $\mathrm{~N}$ & $\%$ & $\mathrm{~N}$ & $\%$ & & \\
\hline Baik & 13 & $\begin{array}{c}33 \\
4\end{array}$ & 5 & $\begin{array}{c}12 \\
8\end{array}$ & 8 & 46,2 & 5,200 & \multirow{3}{*}{0,036} \\
\hline Kurang Baik & 7 & $\begin{array}{c}17 \\
9\end{array}$ & 14 & $\begin{array}{c}35 \\
9\end{array}$ & 10 & 53,8 & \multirow{2}{*}{$\begin{array}{l}1,317- \\
20,539\end{array}$} & \\
\hline Total & 5 & $\begin{array}{c}51 \\
3\end{array}$ & 5 & $\begin{array}{c}48 \\
7\end{array}$ & 39 & 100 & & \\
\hline
\end{tabular}

Sumber: Data Primer

Hasil analisis hubungan antara sikap religiusitas dengan perilaku hidup bersih dan sehat diperoleh bahwa responden dengan sikap religiusitas yang tinggi dengan PHBS

Responden dengan sikap religiusitas rendah dengan PHBS yang baik ada sebanyak 5 (\%), dan responden dengan sikap religiusitas rendah dan memiliki PHBS yang kurang baik ada sebanyak 14 (2,6\%).

Dari hasil uji statistik Chi Square diperoleh nilai $p$ value $=0,036(p<\alpha 0,05)$ yang berarti ada hubungan antara sikap religiusitas dengan perilaku hidup bersih dan sehat. Jadi hipotesis yang menyatakan ada hubungan antara sikap religiusitas dengan perilaku hidup bersih dan sehat terbukti secara statistik. Analisa keeratan hubungan (Odds Ratio) diperoleh nilai OR=5,200 (95\% yang baik ada sebanyak 13 (\%) responden, sedangkan responden dengan sikap religiusitas tinggi tetapi memiliki PHBS yang kurang baik sebanyak 7 (\%) responden. $\mathrm{Cl}=1,317-20,539)$, artinya santri yang memiliki sikap religiusitas rendah berpeluang 5,2 kali memiliki perilaku hidup bersih dan sehat yang kurang baik dibandingkan dengan santri yang mampu memiliki sikap religiusitas yang tinggi.

\section{PEMBAHASAN}

\section{Perilaku Hidup Bersih dan Sehat}

Hasil penelitian menunjukkan bahwa responden memiliki Perilaku Hidup Bersih dan Sehat yang kurang baik. Perilaku Hidup Bersih dan Sehat (PHBS) adalah perilaku seorang individu yang dilakukan untuk menjaga dan 
memelihara baik dirinya maupun lingkungan sekitarnya. Sebagaimana pernyataan dari Dinas Kesehatan (2010), Perilaku Hidup Bersih dan Sehat (PHBS) adalah budaya hidup perorangan, keluarga dan masyarakat yang berorientasi sehat, serta bertujuan untuk meningkatkan, memelihara, dan melindungi kesehatannya baik fisik, mental maupun sosial. Kondisi sehat dapat dicapai dengan mengubah perilaku yang tidak sehat menjadi perilaku sehat dan menciptakan lingkungan yang sehat dan bersih.

Menurut pernyataan dari Ikhwanuddin (2011), pondok pesantren di Indonesia memiliki masalah yang begitu klasik yaitu tentang kesehatan santri dan masalah terhadap penyakit. Masalah kesehatan dan penyakit di pesantren sangat jarang mendapatkan perhatian dengan baik dari warga pesantren itu sendiri maupun masyarakat dan juga pemerintah. Sederhana dan kesahajaan serta kurangnya fasilitas dan sarana di pondok pesantren menjadi salah satu faktor yang mempengaruhi perilaku kesehatan santri dipondok pesantren. Hal ini juga yang menjadi penyebab rendahnya santri yang menerapkan perilaku hidup bersih dan sehat dengan baik.

Teori ini sejalan dengan hasil penelitian yang dilakukan oleh Ariyanti, dkk (2014), dengan hasil penelitian jenis kelamin laki-laki berjumlah 34 responden (48,6\%) dan 26 responden lainnya $(51,4 \%)$ berjenis kelamin perempuan. Usia kurang dari 16 tahun berjumlah 23 responden (32,9\%), responden yang berusia 16-18 tahun berjumlah 47 responden $(67,1 \%)$, dan tidak ada responden yang berusia diatas 18 tahun (0\%). Perilaku responden sebagian besar masuk dalam kategori cukup dengan jumlah 26 responden $(37,11 \%)$. Jumlah responden yang memiliki perilaku dengan kategori kurang berjumlah 23 responden $(32,9 \%)$, dan yang memiliki perilaku baik berjumlah 21 responden $(30,0 \%)$.

Penelitian lain yang dilakukan oleh Nasyith (2018) di salah satu pondok pesantren di Indonesia, hasil dari penelitian ini menunjukan bahwa pola hidup sehat di kalangan pondok pesantren Bahrul Qur'an Sumberadi Mlati Sleman termasuk kedalam kategori "cukup". Dengan hasil pada kategori "sangat kurang" sebesar 6,98\% (3 orang), "kurang" sebesar 18,60\% (8 orang), "cukup" sebesar $41,86 \%$ (18 orang), "baik" sebesar $25,58 \%$ (11 orang), dan "sangat baik" sebesar 6,98\% (3 orang). Berdasarkan hasil dari penelitian sebelumnya tentang PHBS di pondok pesantren, perilaku hidup bersih dan sehat di pondok pesantren dan rumah tahfidz masih tergolong dalam kategori cukup, yang dapat terlihat dari tingginya jumlah hasil dari kategori cukup yang mendominasi hasil dari total keseluruhan hasil dari penelitian diatas.

Perilaku hidup bersih dan sehat (PHBS) yang kini sudah banyak di terapkan di berbagai tatanan mulai dari rumah tangga, institusi pendidikan, tempat kerja, tempat umum, dan fasilitas pelayanan kesehatan sudah mulai berjalan hingga sekarang. Pondok pesantren dan rumah tahfidz yang juga termasuk kedalam tatanan PHBS seringkali kurang mendapatkan promosi 
kesehatan yang dilakukan puskesmas maupun unit layanan kesehatan lainnya. Kesederhanaan dan kesahajaan serta kurangnya fasilitas dan sarana di pondok

\section{Sikap Religiusitas dan Perilaku Hidup Bersih dan Sehat}

Hasil analisis menunjukkan bahwa terdapat hubungan sikap religiusitas dengan perilaku hidup bersih dan sehat. Hasil penelitian ini sejalan dengan teori dari Green (1993) dalam Natoatmodjo (2014), yang menyatakan bahwa sikap adalah salah satu predisposisi untuk munculnya perilaku yang dapat dapat dibuktikan dalam penelitian ini. Penyataan ini diperkuat dengan pernyataan Allport (1954) dalam Natoatmodjo (2014), yang menyatakan bahwa perilaku seseorang akan dipengaruhi oleh kepercayaan/keyakinan, kehidupan emosional dan kecenderungan untuk bertindak atau berperilaku yang semua itu merupakan komponen dari sikap dari seseorang itu sendiri.

Selain itu teori ini sejalan dengan hasil penelitian Yanuarti (2018), tingkat religiusitas masyarakat Kelurahan Dusun Curup Ka upaten Rejang Lebong menunjukkan masyarakat memiliki sikap religiusitas yang sedang (57\%). Religiusitas masyarakat jika dilihat dari dimensi religiusitas diantaranya, dimensi keyakinan yang tinggi sekitar (44\%), dimensi praktek dalam agama Islam masyarakat yaitu (27\%) dimensi praktek ibadah tinggi, kategori sedang berjumlah (62\%), dan (11\%) kategori rendah. pesantren dan rumah tahfidz menjadi salah satu faktor yang mempengaruhi perilaku kesehatan santri tidak dapat diterapkan dengan baik.

Masyarakat kelurahan Dusun Curup memiliki pengalaman keagamaan yang sedang (57\%), anggota masyarakat yang memiliki dimensi pengetahuan keagamaan tinggi (41\%), masyarakat dusun curup memiliki dimensi konsekuensi beragama yang sedang (61\%). Tingkat perilaku hidup bersih dan sehat (PHBS) tinggi sebesar 24\%, 56\% masyarakat kategori sedang, dan 20\% kategori rendah. Jadi dapat disimpulkan bahwa masyarakat Kelurahan Dusun Curup memiliki perilaku hidup bersih dan sehat (PHBS) yang sedang.

Dari hasil penelitian yang didapatkan peneliti berasumsi, bahwa dari rendahnya sikap religiusitas seseorang maka akan dapat berdampak buruk pula pada perilaku hidup bersih dan sehat, begitu pula dengan tingginya sikap religiusitas seseorang makaakan dapat berdampak baik pada perilaku hidup bersih dan sehat seseorang. Akan tetapi hal ini juga tidak terlepas dari berbagai faktor lain seperti pengetahuan, berbagai fasilitas yang tersedia, dan kebiasaan buruk dari seseorang itu sendiri.

Berdasarkan hasil dari penelitian, konsep teori, penelitian terkait dan asumsi penelitian diatas, peneliti menyimpulkan bahwa ada hubungan yang yang erat antara sikap religiusitas dengan perilaku hidup bersih dan sehat. Santri sikap religiusitas yang tinggi maka akan memiliki perilaku hidup bersih dan 
sehat yang baik, sedangkan santri yang memiliki sikap religiusitas yang rendah maka akan perilaku hidup bersih dan sehat yang kurang baik.

\section{KESIMPULAN}

Terdapat hubungan yang bermakna antara hubungan antara sikap religiusitas dengan perilaku hidup bersih dan sehat di rumah tahfidz (Rumah Qur'an Mulia) Palembang dengan $p$ velue $(0,036)$. Hasil dari analisa keeratan hubungan (Odds Ratio) diperoleh nilai OR=5,200 $(95 \% \mathrm{Cl}=1,317$ 20,539), yang berarti santri yang memiliki sikap religiusitas rendah berpeluang 5,2 kali memiliki perilaku hidup bersih dan sehat yang kurang baik dibandingkan dengan santri yang mampu memiliki sikap religiusitas yang tinggi.

\section{DAFTAR PUSTAKA}

Ahmadi, Abu dkk. (1999). Psikologi Sosial. Jakarta: Rineka Cipta. Cet. 2..

Ariyanti, Maelina, et,all. 2014. Pengaruh PHBS dengan Pengetahuan PHBS Pada Remaja di Pondok Pesantren Ulil Albaab Desa Prian Kabupaten Lombok Timur. Jurnal Edisi Agustus 2014 - Januari 2015

Bimo, Walgito. (2001). Psikologi sosial. Yogyakarta: Andi Offset

Departemen Kesehatan RI. 2010. Pedoman

Perilaku Hidup Bersih dan Sehat. Jakarta:

Depkes RI -. 2010. Riset Kesehatan Dasar Tahun 2010. Jakarta: Depkes RI
Djamaludin, Ancok dan Fuad Nasori Suroso. 2011. Psikologi Islami: Solusi Islam atas Problem-Problem psikologi. Yogyakarta: Pustaka Pelajar.

Ikhwanuddin, Alim. 2011. Perilaku Kesehatan

Santri: (Studi Deskriftif Perilaku Pemeliharaan Kesehetan, Pencarian dan Penggunaan Sistem Kesehatan dan Perilaku Kesehatan Lingkungan di Pondok Pesantren Assalafi Al Fithrah Surabaya). Jurnal Sosial Dan Politik Universitas Airlangga Surabaya.

Kemenkes RI 2010. Laporan Kinerja Satu Tahun. Pemberdayaan Masyarakat dan Promosi Kesehatan Untuk Hidup Sehat. Jakarta: Kemenkes RI Pusat Promosi Kesehatan.

2011. Peraturan Menteri Kesehatan Republik Indonesia nomor: 2269/MENKES/PER/XI/2011 Pedoman Pembinaan Perilaku Hidup Bersih dan Sehat (PHBS). Jakarta: Kemenkes RI Pusat Promosi Kesehatan.

Mahardika, Esan Bayu. 2013. Peran Rumah Tahfidz Zulfa Qurrotaayun dalam Pemberdayaan Masyarakat di Desa Purbayan Kota Gede Yogyakarta. Yogyakarta: Fakultas Dakwah UIN Sunan Kalijaga.

Nashori, Fuad dan Mucharam, Diana. Mengembangkan Kreatifitas dalam Psikologi Islam. Yogyakarta; Menara Kudus. 2002.

Nasyith, Ahmad Dzaky. 2018. Pola Hidup Sehat di Pondok Pesantren Bahrul Qur'an Jonggrangan Sumberadi Mlati Sleman. 
Fakultas IImu Keolahragaan Universitas Negeri Yogyakarta.

Notoatmodjo, Soekidjo. 2003. Pendidikan dan perilaku kesehatan. Jakarta: Rineka Cipta.

----------. 2010. Metodologi penelitian kesehatan. Jakarta: Rineka Cipta.

2014.IImu Perilaku Kesehatan.

Jakarta: Rineka Cipta.

Nugraheni, Dwi Nurlina. 2008. Pengaruh Tentang Kebersihan diri terhadap timbulnya Skabies (Gudik) pada santriwati dipondok Pesantren Al-Muayyad Surakarta. Universitas Muhammadiyah Surakarta: Jurnal Volume 05 No. 4, Desember 2012.

Nurjanah, Siti. 2014. Pengaruh Tingkat Religiusitas terhadap Perilaku Disiplin Remaja di Man Sawit Boyolali. Fakultas IImu Tarbiyah dan Keguruan Universitas Islam Negeri (UIN) Syarif Hidayatullah Jakarta.

Parman, et.al. 2017. Faktor Risiko Hygiene Perorangan Santri terhadap Kejadian Penyakit Kulit Skabies di Pesantren Albaqiyatushshalihat Tanjung Jabung Barat
Tahun 2017. Jurnal IImiah Universitas Batanghari Jambi Vol.17 No.3 Tahun 2017. Rachmatan, Risana, et.al. 2016. Religiusitas Dengan Gaya Hidup Hedonisme: Sebuah Gambaran Pada Mahasiswa Universitas Syiah Kuala. Univesitas Syiah Kuala: Jurnal Psikologi, Volume 12 Nomor 2, Desember 2016.

Rifqi. 2011. Hubungan antara tingkat Religiusitas dengan Sikap terhadap Pornoaksi pada Mahasiswa Sekolah Tinggi IImu Ekonomi (STIE) Perbanas. Universitas Islam Negeri (UIN) Syarif Hidayatullah Jakarta.

Yanuarti, Eka. 2018. Pengaruh Sikap Religiusitas Terhadap Perilaku Hidup Bersih dan Sehat Masyarakat Kabupaten Rejang Lebong. Bengkulu: Sekolah Tinggi Agama Islam Negeri (STAIN) Curup.

Zuhriya, Rizka ihromatuz. 2015. Perilaku Hidup Bersih dan Sehat Santri di Pondok Pesantren Mamba'us Syafa'atil Qur'an (Clean and Healthy Behavior Of Santri in Pondok Pesantren Mambau'us Syafa'atil Quran). Jurnal Ners dan Kebidanan, Volume 2, Nomor 3, Desember 2015. 